\title{
BLACK SEA NAVAL ACCIDENTS - INTERVENTION MANAGEMENT
}

\author{
Article DOI: https://doi.org/10.35219/mtd.2019.2.02 \\ Valerian NOVAC*, Eugen RUSU, Gheorghe STĂVĂRACHE
}

\author{
”Dunărea de Jos" University, Galati, ROMANIA \\ *Corresponding author: gstavarache82@yahoo.com
}

\begin{abstract}
Most of the global trade is carried by sea as the Earth surface is covered more than $3 / 4$ with water. For commercial purposes, the size of ships has continuously increased; thus, the space for cargo and passengers became more generous. Though, this leads to higher risks: reduced maneuverability, especially in narrow or confined waters, more costly intervention in case of an accident and consistent relief actions. When naval accidents affect the property, human life and environment are severely affected. To reduce the risk of accidents or curb their effects when produced, all stakeholders involved in shipping must obey the provisions of international regulations related to the safety of ships operations, collision avoidance, pollution prevention, and so on. Along with enforcing international regulations in the field, effective management of intervention in the case of an accident has to be adopted. This paper presents the influence of environmental factors in the western Black Sea basin on naval accidents, along with considerations related to the system of intervention in the case of distress situations or accident in the Romanian sector of the Black Sea.
\end{abstract}

Keywords: Black Sea, naval, accident, safety, intervention

\section{INTRODUCTION}

Situated in the south-east of Europe, the Black Sea is usually referred to as a semi-enclosed sea or narrow sea, due to its particular situation: it is connected to the Marmara Sea through Bosporus Strait and else with the Mediterranean Sea, by Dardanelles. Kerch Strait connects the Black Sea at its northeastern side with the Azov Sea [1].

From bathymetric point of view, the sea basin may be seen as consisting of two sub-basins, separated by a rim lying $\mathrm{S}$ of the Crimean Peninsula, the northwestern sub-basin is defined by shallow depths up to 100 miles from the shore, while the southeastern one has a more narrow shelf and waters are more rooted, there is reached the maximum depth of the Black Sea, $2200 \mathrm{~m}$ [2].
From maritime accidents analysis point of view (Fig. 1), the northwestern part of the Black Sea, our study target area, is more facilitating groundings of ships due to shallow waters and limited ability to maneuver, especially in the main harbors' area, where the traffic is dense.

Constanta harbor is the biggest in the Black Sea and the fourth in Europe, favored by its geographical location at the intersection of two pan-European corridors: inland waters and railway. This port has a considerable hinterland, almost the whole European continent, is served by 2 satellite ports: Midia and Mangalia, these satellites may be seen as specialized ports [3], [4].

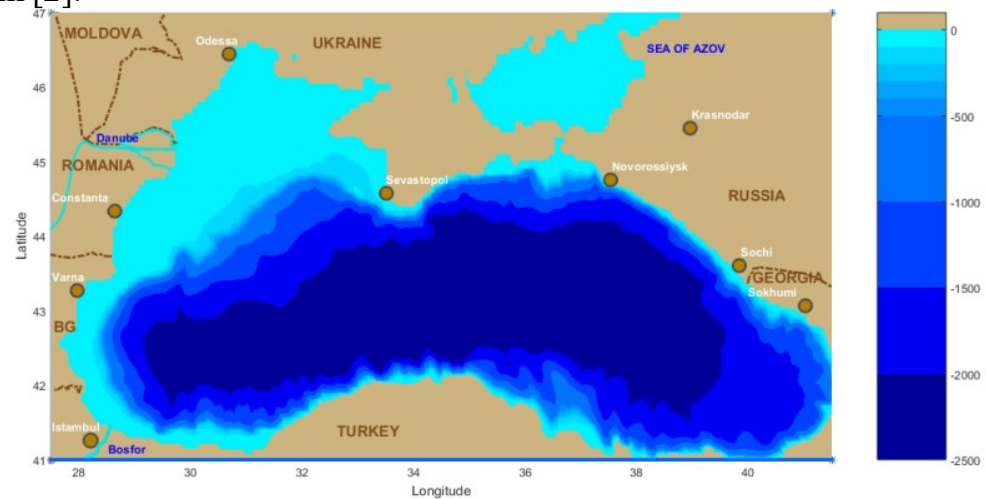

Fig. 1. The Black Sea bathymetric map 
As concerning the navigation conditions in the Black Sea, it is well known that, sometimes, along northwestern coastal area, severe storms occur, with a negative impact on navigation, producing significant damages to ships hull or port assets [5], [6].

A maritime accident is an unpredictable and unusual event that occurred due to an unknown matter or is an uncommon effect of a common cause [7]. Usually, when occurring, a naval accident has a negative impact on environment, society, and economy [8].

The most common types of naval accidents are collision, allision, capsize, sinking, grounding, stranding, fire, and explosion [7], [9].

Table 1. Accident contributing factors [7]

\begin{tabular}{|l|l|}
\hline \multicolumn{1}{|c|}{ Category } & \multicolumn{1}{c|}{ Factor } \\
\hline $\begin{array}{l}\text { Natural } \\
\text { conditions }\end{array}$ & $\begin{array}{l}\text { current, tide, wind, poor visibility, } \\
\text { stormy sea }\end{array}$ \\
\hline $\begin{array}{l}\text { Ship-related } \\
\text { factors }\end{array}$ & $\begin{array}{l}\text { weak ship of considerable size, } \\
\text { poor maneuvering ability and or } \\
\text { stability, draught restraints }\end{array}$ \\
\hline $\begin{array}{l}\text { Cargo-related } \\
\text { factors }\end{array}$ & $\begin{array}{l}\text { awkward cargo, place of storage, } \\
\text { degree of vigilance needed }\end{array}$ \\
\hline $\begin{array}{l}\text { Route } \\
\text { conditions }\end{array}$ & $\begin{array}{l}\text { navigational errors, confined } \\
\text { waters, restricted passages, marine } \\
\text { hazards }\end{array}$ \\
\hline Human errors & $\begin{array}{l}\text { skill-based, misperception, } \\
\text { judgment, decision-making, } \\
\text { communication, stress }\end{array}$ \\
\hline $\begin{array}{l}\text { Technical } \\
\text { failures }\end{array}$ & corrosion, steering, engine, hull \\
\hline $\begin{array}{l}\text { Assistance } \\
\text { administered }\end{array}$ & $\begin{array}{l}\text { the weak performance of } \\
\text { equipment, inadequate disposition }\end{array}$ \\
\hline
\end{tabular}

An accident is not the result of solely one factor or one category of factors, it is a mix of factors, and the latest research indicates that in most situations, human errors are the main factor triggering the accidents [10].

It is essential to enhance search and rescue (SAR) and intervention in distress situations capabilities. Thus, it is required to be developed an integrated system for management and intervention consisting of: Integrated Management Center, disposition points for intervention equipment and assets, simulator meant to support modeling of distress situations, and a system able to analyze and transmit data regarding level of pollutant from the accident scene to Integrated Management Center [11].

For Romanian sector of the Black Sea, the Romanian Naval Authority is the body responsible with coordination in case of accident through Maritime Coordination Centre (MCC), while the means of intervention rests with the body in charge of safety of life at sea and SAR, Romanian Agency of Safety of Life at Sea (RASLS).

RASLS owns only a multi-functional tug able to operate up to sea state 7, but MCC can ask for assistance from Romanian Navy, Border Police and other stakeholders able to support the intervention.

\section{METHODOLOGY}

This paper investigates the worst naval accident ever occurred in the external basin of Constanta Port on the $04^{\text {th }}$ January 1995. Mainly, it analyzes in a mirror, the crew and authorities responsible with intervention.

Meteorological conditions are:

- wind - speed $\sim 31 \mathrm{~m} / \mathrm{s}$ : - direction N, E, NE,

- wave height $\sim 9 \mathrm{~m}$,

- visibility: <1 nautical mile (NM),

- precipitation: blizzard,

- cold water and air [12]

Paris ship (former FOTINI) features:

- type: bulk carrier,

- deadweight: 25957 ,

- length: $174.1 \mathrm{~m}$,

- beam: $25.51 \mathrm{~m}$,

- draft: $9.95 \mathrm{~m}$.

The experts concluded that such a storm takes place once in 10-12 years, but rarely so close to the shore.

It is to be noted that at the same time with Paris, MCC was coordinating the response actions for one more ship: You Xiu with the same result - ship sunk, no survivors.

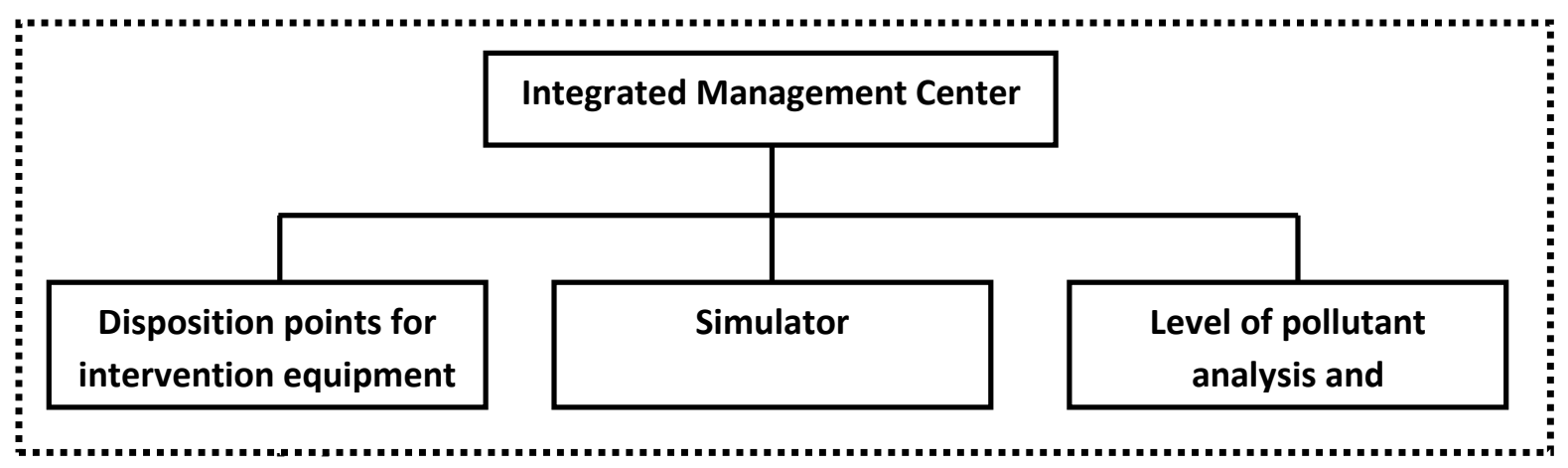

Fig. 2. Management and intervention integrated system 
Table 2. Event synchromatrix [12]

\begin{tabular}{|c|c|c|}
\hline Time & Crew actions & Authorities actions \\
\hline \multicolumn{3}{|c|}{ 04.01.1995 } \\
\hline $\begin{array}{l}09.00 \\
\text { LT }\end{array}$ & $\begin{array}{l}\text { Paris in ballast, at anchor in the external basin } \\
\text { (3.8 NM of N breakwater) of Constanta Port. } \\
\text { Requested refueling. }\end{array}$ & $\begin{array}{l}\text { Approved refueling and sent pilot ship Atlas at the } \\
\text { end of the breakwater to assist. }\end{array}$ \\
\hline $\begin{array}{c}14.15 \\
\text { LT }\end{array}$ & $\begin{array}{l}\text { Report a defective windlass and maintenance } \\
\text { work on it. }\end{array}$ & $\begin{array}{l}\text { Instruct Paris to weigh the anchor and link-up with } \\
\text { Atlas. }\end{array}$ \\
\hline $\begin{array}{c}17.00 \\
\text { LT }\end{array}$ & $\begin{array}{l}\text { Still working on the defective windlass, } \\
\text { remain at anchor until the next morning. } \\
\text { Request port authorities to advise ships in the } \\
\text { area about its condition. }\end{array}$ & Inform all ships regarding the Paris situation. \\
\hline $\begin{array}{c}18.10 \\
\text { LT }\end{array}$ & No action. & Inform Paris shipmaster that its anchor drifted. \\
\hline $\begin{array}{l}19.00 \\
\text { LT }\end{array}$ & $\begin{array}{l}\text { Paris reported that its rudder was hard to } \\
\text { starboard and the engine full ahead, but the } \\
\text { ship didn't respond. Due to heavy wind Paris } \\
\text { got a position parallel with the breakwater. }\end{array}$ & $\begin{array}{l}\text { Notice that Paris reached a point at } 0,55 \mathrm{NM} \text { of the } \\
\text { breakwater and warned the shipmaster again. }\end{array}$ \\
\hline $\begin{array}{l}19.50 \\
\text { LT }\end{array}$ & $\begin{array}{l}\text { Issued S.O.S distress signal and the } \\
\text { shipmaster requested a phone call with the } \\
\text { ship-owner in Atena. }\end{array}$ & $\begin{array}{l}\text { Facilitate the requested phone call and sent } \\
\text { Viteazul rescue tug in assistance. Viteazul reached } \\
\text { the corresponding position of Paris but in the } \\
\text { internal basin and observed that Paris had no lights } \\
\text { on. }\end{array}$ \\
\hline $\begin{array}{l}20.30 \\
\text { LT }\end{array}$ & $\begin{array}{l}\text { Shipmaster messaged port authorities that aft } \\
\text { part of the ship has sunk. }\end{array}$ & - \\
\hline $\begin{array}{c}21.45 \\
\text { LT }\end{array}$ & - & $\begin{array}{l}\text { Viteazul at anchor in the internal basin - Paris } \\
\text { sunk. }\end{array}$ \\
\hline \multicolumn{3}{|c|}{05.01 .1995} \\
\hline $\begin{array}{c}00.15 \\
\text { LT }\end{array}$ & $\begin{array}{l}\text { Due to bad weather failed to assist with } \\
\text { terrestrial or aerial means. }\end{array}$ & $\begin{array}{l}\text { Viteazul reported that just a mast of Paris could be } \\
\text { observed above water. }\end{array}$ \\
\hline
\end{tabular}

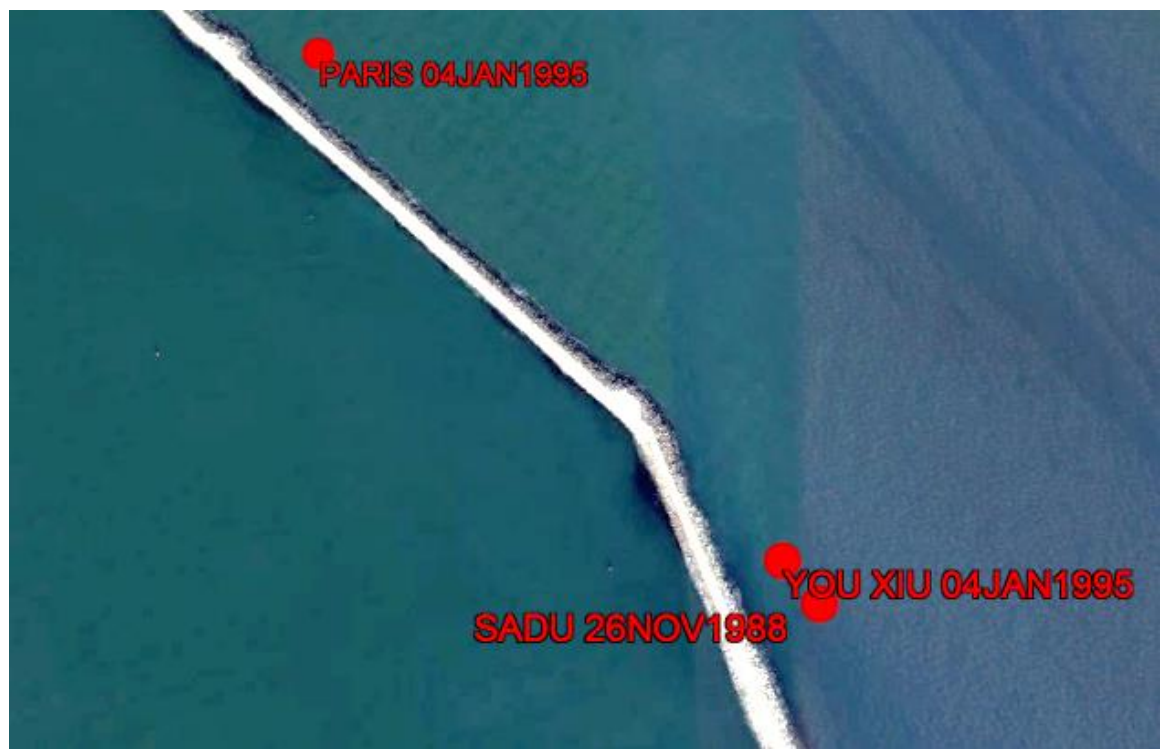

Fig. 3. Wrecks positions of Paris, You Xiu and Sadu

\section{RESULTS AND DISCUSSIONS}

The paper analyzes the tragedy of ship Paris from the perspective of all categories of factors.

Natural conditions: the unexpected violent storm occurred very close to the shore, with lousy visibility and very cold seawater and air.
Ship-related factors: ship in ballast was, probably the reason for what ship did not respond when the crew put engine full ahead and rudder hard to starboard.

Cargo-related factors: no impact - holds empty.

Route conditions: the proximity of breakwater, incapacity to maneuver. 
Human errors: this category is the dominant one most decisive factors related to the disaster of the ship rests in this category.

Lack of respect for rules and procedures - the shipmaster ignored all port authorities' warnings and exposed the ship and the crew. Some necessary actions were taken too late, with no effect: they tried to change position just very close to breakwater and the ship did not respond. The shipmaster never asks for assistance before the ship was starting to sink. The ship owner instructed the master to struggle to keep the ship instead of guiding him to save crew members' life. At the same time, the crew members just obeyed exactly the skipper orders and did not try to advise him in any way in relationship with the danger of losing the ship and putting in danger the lives of the crew members.

Technical failures: the defective windlass was the central element of this tragedy, doubled by the incapacity of ship to steer close of the breakwater. No one considered abandoning the anchor.

Administered assistance: even though port authorities warned few times the shipmaster regarding the potential disaster of the ship, they sent very late in assistance the rescue tug Viteazul, a ship incapable of sea worthiness with such a sea state. Viteazul never exits the internal basin of the port, just observed and reported what happened with Paris and the other ship in distress, You Xiu.

The rescue teams did not prove enough determination to succeed in rescuing the ship Paris. Despite the painful experience of ship Sadu, sunken in similar conditions just 8 years before, poor management of intervention was observed during this disastrous incident.

\section{CONCLUSIONS}

It is of paramount importance as a tool for port authorities to have the ability to analyze the wave regime, effect of the wind and temperature for the northwestern part of the Black Sea and to take the best intervention decisions.

Using adequate means and equipment for intervention and maintaining them in an operational state is of crucial importance. Testing this equipment and all means of intervention for different situations and worst hydro meteorological situations and scenarios is also necessary.

As one may notice from the tragedy of Paris bulk carrier, the onboard management and shipping company management require adequate improvements to avoid such tragedies in the future.

\section{ACKNOWLEDGMENT}

This work was carried out in the framework of the research project REMARC (Renewable Energy extraction in MARine environment and its Coastal impact), supported by the Romanian Executive Agency for Higher Education, Research, Development, and Innovation Funding-UEFISCDI, grant number PN-III-P4-IDPCE-2016-0017.

\section{REFERENCES}

[1] Novac V., Rusu E., 2018, Black Sea littoral military operations - environment impact, Scientific Bulletin of Naval Academy, Romania, pp. 607-616.

[2] Publication140 - Sailing Directions (Planning Guide), North Atlantic Ocean and adjacent seas, National Geospatial-Intelligence Agency, 2017. [3] *** Constanza Port,

http://www.portofconstantza.com, accessed on 01.05 .2019

[4] Onea F., Diaconu S., Rusu E., 2018, Evaluation of the environmental conditions in the vicinity of the Romanian ports at the Black Sea, Constanta Maritime University Annals, 19, pp. 143-149.

[5] Vespremeanu A., Preoteasa L., Tătui F., 2014, Oceanografie fizică, Editura Ars Docendi, p. 171.

[6] Chiotoroiu B., Ciuchea V., 2008, The grounding of two cargo ships near the Romanian Black Sea coast. Meteorological conditions analysis, Constanta Maritime University Annals, 19, pp 143-149.

[7] Akten N., 2006, Shipping accidents: a serious threat for marine environment, Journal of the Black Sea / Mediterranean Environment, 12, pp. 269-304.

[8] Awal Z., Hasegawa K., 2017, A study on accident theories and application to maritime accidents, Procedia Engineering, 194, pp 298-306.

[9] *** European Maritime Safety Agency, http://www.emsa.europa.eu/, accessed 01.05.2019 23.00 .

[10] Celik M., Cebi S., 2009, Analytical HFACS for investigating human errors in shipping accidents, Accident analysis and prevention, 41, pp 66-75.

[11] Chițac V., Toma A., Atodiresei D., 2014, Integrated Management System for intervention in maritime accidents and distress situations on the Black Sea, "Mircea cel Bătrân" Naval Academy Scientific Bulletin, 17(2), pp. 10-13.

[12] Cumpănă C., Cumpănă A.D., 2008, Naufragiul navelor "Paris" și "You Xiu" cel mai mare accident naval din istoria portului Constanța, Telegraf advertising, ISBN 978-973-87526-4-1, Constanța.

[13] *** Romanian Black Sea Wrecks, http://www.blackseawrecks.ro, accessed 02.05.2019 13.00 . 